\title{
Work-Related Musculoskeletal Disorders at Two Textile Factories in Edirne, Turkey
}

Ufuk Berberoğlu, Burcu Tokuç

Department of Public Health, Faculty of Medicine, Trakya University, Edirne, Turkey

\section{ABSTRACT}

Objective: "Work-related musculoskeletal disorders" (WMSDs) is a term used to describe a painful or disabling injury to the muscles, tendons or nerves caused or aggravated by work. WMSDs are preventable or at least can be delayed. The aim of this study to determine the work related musculo-skeletal disorders and risk levels of the these factory workers.

Study Design: Cross sectional study.

Material and Methods: This is a cross-sectional study conducted at two textile factories in Edirne, Turkey and it involved 381 workers. The questionnaire used for data collection consisted of two parts. The first part described some socio-demographic features, working conditions and health problems of workers in the previous four weeks. In the second part, a Rapid Upper Limb Assessment (RULA) Employer Assessment worksheet was used.

Results: In the assessment of the upper limbs of the workers, the arm/wrist score (AWS) is 5.9 \pm 1.7 (3-11); neck, trunk, legs score (NTLS) is 5.3 \pm 2.5 (3-11); and total score (TS) is $5.5 \pm 1.3(3-7)$. The ages of the workers are significantly associated with higher RULA scores $(r=0.207, p=0.000)$. AWS, NTLS and TS of the women workers were found to be statistically significantly lower than for the men.

Conclusion: Musculoskeletal disorders are a common problem among textile workers. Employers can prevent WMSD hazards by properly designing the jobs or workstations and selecting the appropriate tools or equipment.

Key Words: Work-related musculoskeletal disorders, ergonomics, upper limb

Received: 13.06.2012

Accepted: 09.07.2012

\section{Introduction}

"Work-related musculoskeletal disorders" (WMSDs) is a term used to describe a painful or disabling injury to the muscles, tendons or nerves caused or aggravated by work (1). WMSDs are preventable or at least can be delayed (2).

Work-related musculoskeletal disorders were first noticed by Bernardino Ramazzini, who documented the disorders that he saw in workers with "insistent and irregular movements in unnatural postures." These work-related disorders of the neck, shoulder, lower back, upper limbs and locomotor organs continue to be of the interest to workers, researchers and companies due to the significant temporary or permanent disability of workers; symptoms such as pain, numbness and tingling; time off from work; reduced productivity; increased worker's compensable costs; and the increasing number of associated cases coming before the courts (3).

Work-related musculoskeletal disorders have become a major problem in many industrialized countries (4). These disorders are widespread in many countries, with substantial costs and impacts on the workers' quality of life. They also constitute a major proportion of all registered and/or compensation-eligible, work-related diseases in many coun- tries. Upper-extremity musculoskeletal disorders are highly prevalent in manual-intensive occupations such as clerical work, postal services, cleaning, industrial inspections and packaging. Both experimental science and epidemiology indicate that job features that increase the risks of work-related WMSDs are heavy lifting, repetitive hand motions, static work in which the body is maintained in a fixed posture, vibrations and any of these in combination along with an undesirable psychosocial work environment.

Work-related musculoskeletal disorders are a worldwide problem. In developing countries, especially those with high rates of unemployment, it is tempting for employers who build up small and middle-sized industries to disregard safety and health $(5,6)$. In the private sector in the United States, nearly six million workers experience non-fatal injuries or illnesses (7). In Britain, musculoskeletal disorders are believed to represent the largest category of work-related illness (8). In Europe, WMSDs are the most common work-related health problem, affecting millions of workers. Across the EU 27, 25\% of workers complain of backaches and $23 \%$ report muscular pains. Workrelated musculoskeletal disorders are caused mainly by manual handling, frequent bending and twisting, heavy physical work and whole-body vibration. The risk of WMSDs can increase 
with an increase in workloads, low work satisfaction, high work demands and work-related stress (9). WMSDs affect millions of European workers across all employment sectors with the highest rates in the agriculture and construction sectors. For example, WMSDs affect one million people in Great Britain each year and the most common problems are back pain, work-related neck and upper limb disorders (ULDs), repetitive strain injuries and lower limb disorders (10).

In the past two decades, observational methods have been developed to facilitate a quantitative assessment of physical loads at workplaces. In many occupations, exposure to a physical load is not limited to one physical factor but encompasses many factors such as trunk flexion, rotation, lifting and carrying. Often these physical factors are strongly correlated (11).

Work-related musculoskeletal disorders account for $34 \%$ of all lost-workday injuries and illnesses. Employers report nearly 600.000 WMSDs requiring time away from work every year. These disorders account for $\$ 1$ of every $\$ 3$ spent for workers' compensation. Each year, WMSDs account for more than $\$ 15$ billion to $\$ 20$ billion in workers' compensation costs. Total direct costs add up to as much as $\$ 50$ billion annually. On average, it takes a worker 28 days recover from carpal tunnel syndrome, which is longer than the time needed to recover from an amputation or a fracture. Workers with severe injuries can face permanent disability that prevents them from returning to their jobs or handling simple, everyday tasks (9).

European standards focus on allowable parameters relating to posture, exerted force and the frequency of movements. These parameters determine musculoskeletal loads that might cause WMSDs. The relevant standards are as follows:

- EN-614-1: Safety of machinery, ergonomic design principles and terminology and general principles; presents overall rules related to design process with consideration of anthropometry and biomechanics.

- EN 614-2: Safety of machinery, ergonomic design principles and interaction between machinery design and work tasks.

- EN-1005-4: Safety of machinery, human physical performance and evaluation of working postures in relation to machinery.

- EN ISO 9241-2: Ergonomic requirements for office work with visual display terminals (VDTs); guidance on task requirements (12).

Employment in the garment industry rose worldwide in the late 1990s to approximately 11 million in 1998. In the United States, over 300.000 garment workers were employed in 2005 to sew apparel (13). Upper-body WMSD is a common adverse health effect among garment workers. Work, organizational, and personal factors were associated with the increased prevalence of moderate to severe upper-body musculoskeletal pain among garment workers (14).

The textile and apparel industries are dominant sectors in Turkey (15). The proportion of textiles and apparel in Turkish exports is $10 \%$ (16). These industries constituted $13.6 \%$ of the general employment in Turkey and supply $10 \%$ of Turkey's GNP. Approximately two million workers are employed in these two industries $(450,000$ in textiles and 1.5 million in apparel manufacturing) (16).

The objective of this study is to determine the WMSDs of upper extremities among workers at two textile factories at which these disorders have frequently been seen.

\section{Material and Methods}

This is a cross-sectional study conducted at two textile factories in Edirne, Turkey and it involved 381 workers. The questionnaire used for data collection consisted of two parts. The first part described some socio-demographic features, working conditions and health problems of workers in the previous four weeks. In the second part, a Rapid Upper Limb Assessment (RULA) Employer Assessment worksheet was used. RULA was developed by Atamney and Corlett in 1992 to determine the upper limb movements that caused musculoskeletal system disorders. Muscular functions and neck, body and upper limb posture disorders are evaluated by grading them from 1 to 4 on the RULA scale $(17,18)$. The data was evaluated in SPSS Ver. 13.0. Descriptive statistics, student t-test, Pearson Chi-Square and Pearson Correlation analyses were used.

\section{Results}

The socio-demographic features of workers are presented in Table 1. In the assessment of the upper limbs of the workers, the arm/wrist score (AWS) is $5.9 \pm 1.7$ (3-11); neck, trunk, legs

Table 1. Socio-demographic features of workers $(n=381)$

\begin{tabular}{|c|c|c|c|}
\hline \multicolumn{2}{|l|}{ Features } & \multicolumn{2}{|c|}{ Mean $\pm S D$ (min.-max.) } \\
\hline \multicolumn{2}{|l|}{ Age } & \multicolumn{2}{|c|}{$31.5 \pm 6.3(17-52)$} \\
\hline \multicolumn{2}{|l|}{ Employment period } & \multicolumn{2}{|c|}{$11.11 \pm 6.07(1-35)$} \\
\hline \multicolumn{2}{|l|}{ Working time/week } & \multicolumn{2}{|c|}{$45.8 \pm 1.77(40-65)$} \\
\hline \multirow{3}{*}{ Gender } & & Jumber & $\%$ \\
\hline & Men & 257 & 67.5 \\
\hline & Women & 124 & 32.5 \\
\hline \multirow[t]{5}{*}{ Educational Period } & 5 years & 125 & 33.4 \\
\hline & 8 years & 61 & 16.3 \\
\hline & 12 years & 171 & 45.7 \\
\hline & 14 years & 14 & 3.8 \\
\hline & 16 years & 3 & 0.8 \\
\hline \multirow[t]{3}{*}{ Marital Status } & Married & 264 & 69.3 \\
\hline & Single & 109 & 28.6 \\
\hline & Widoved/Divorced & 8 & 2.1 \\
\hline \multicolumn{2}{|c|}{ Having a chronic illness } & 27 & 7.4 \\
\hline \multicolumn{2}{|c|}{ Having min. 1 occupational accident } & 64 & 16.9 \\
\hline \multicolumn{2}{|c|}{$\begin{array}{l}\text { Having an ache that affect job efficiency } \\
\text { in the last month }\end{array}$} & 37 & 10.5 \\
\hline \multicolumn{2}{|c|}{ Regularly doing exercises } & 38 & 10 \\
\hline \multicolumn{2}{|l|}{ Smoking } & 176 & 46.4 \\
\hline
\end{tabular}


score (NTLS) is $5.3 \pm 2.5$ (3-11); and total score (TS) is $5.5 \pm 1.3$ (3-7). The ages of the workers are significantly associated with higher RULA scores $(r=0.207, p=0.000)$. Thirty-seven workers $(10.6 \%)$ reported that they have had musculoskeletal complaints and the complaints were significantly higher for women workers $(16.5 \%)$ than in men $(7.7 \%)\left(\chi^{2}=6.415, p=0.011\right)$. AWS, NTLS and TS of the women workers were found to be statistically significantly lower than for the men (Table 2). Duration of employment for more than 10 years was significantly associated with higher RULA scores (Table 2).

The mean total score (TS) of workers is $5.4 \pm 0.9$ in the spinning department, $4.5 \pm 1.1$ in the apparel manufacturing department, $6.0 \pm 1.0$ in the weaving department and $6.5 \pm 10$ in textile chemicals department.

\section{Discussion}

Observational assessments could be made about WMSDs using RULA as they could be made using laboratory methods for clinical diagnoses. Work-related musculoskeletal disorders frequency was high in the textile sector. Punnett et al. (19) found significantly increased rate ratios for pain in the shoulder and wrist and hand, as well as for the presence of carpal tunnel syndrome (CTS) symptoms among garment workers performing stitching and finishing. More recently, after adjusting for the "healthy worker effect," a cross-sectional study compared the prevalence of soft-tissue disorders in female garment workers and hospital staff.

Sokas et al. (20) compared sewing machine operators to a subset of the general population matched for age, race, and gender and weighted toward lower socioeconomic groups and minority populations. They found that sewing machine operators had a higher prevalence of self-reported upperback and upper-extremity pain. Wang et al. (14) study results indicate that both personal and work-related factors are associated with the increased prevalence of upper-body WMSDs among sewing machine operators. Ulu et al. (21) found the proportions who still have lumbago in a section of musclesceletal system is $53.6 \%$.

In line with our results, Hagberg et al. (22) reported muscular pain in the neck and shoulder as being more frequent among females than males in both the general and worker populations. Many studies have reported gender differences in the prevalence of musculoskeletal complaints. For example, in a large population-based study in the Netherlands, $79.3 \%$

Table 2. RULA Scores of workers

\begin{tabular}{|lccc|}
\hline \multicolumn{1}{c}{ AWS } & NTLS & TS \\
\hline Women & $5.4 \pm 0.9$ & $4.0 \pm 1.7$ & $4.8 \pm 1.1$ \\
Men & $6.2 \pm 1.8$ & $5.9 \pm 2.5$ & $5.8 \pm 1.2$ \\
$\mathrm{p}$ & 0.000 & 0.000 & 0.000 \\
Working $\leq 10$ years & $5.7 \pm 1.5$ & $4.9 \pm 2.2$ & $5.3 \pm 1.3$ \\
Working $>10$ years & $6.1 \pm 1.8$ & $5.7 \pm 2.6$ & $5.7 \pm 1.3$ \\
p & 0.013 & 0.003 & 0.002 \\
\hline AWS: Arm/wrist score, NTLS: Neck, trunk, legs score, TS: Total score \\
\hline \multicolumn{4}{l}{} \\
\hline
\end{tabular}

of the women and $71.5 \%$ of the men reported one or more musculoskeletal complaints in the past year (23). The oneyear prevalence of self-reported spinal pain (including lower back, upper back and neck) in a sample of 35-to 45-year-old Swedish residents was $69.5 \%$ for women and $63.2 \%$ for men (24). Moreover, in physically strenuous tasks, the women had a higher risk than the men. These associations were independent of age.

Women, rather than men, in high-strain jobs were more likely to report back problems (odds ratio (OR) 1.60, 95\% confidence interval $(95 \% \mathrm{Cl}) 1.14$ to 2.28$)$ and restricted activity (OR $1.98,95 \% \mathrm{Cl} 1.16$ to 3.48 ) compared with those in lowstrain jobs. High physical exertion was an independent predictor of back problems for both sexes. Conversely, chronic back problems contributed explaining the high job-related strains among women (OR 1.76,95\% $\mathrm{Cl} 1.30$ to 2.39) and high physical exertion among men (OR $1.39,95 \% \mathrm{Cl} 1.09$ to 1.77$)$, whereas restricted activity due to musculoskeletal disorders contributed to the explanation of high job insecurity among both sexes (25). The risk of male workers suffering from a WMSD is 1.3 times higher than the risk to female workers: $35 / 100.000$ compared to $27 / 100.000$. In terms of self-reported, work-related WMSD complaints, the risk is only slightly higher among male workers (1.07 times higher).

As in our results, the number of WMSD complaints increases with age. At the age of 55-64 years, the number of self-reported symptoms is 1.7 times higher than at the age of 25-34 years (13).

The duration of employment is significantly associated with high RULA scores in our study, as Lemasters et al. (26) found. The duration of employment as a carpenter for more than 20 years was significantly associated with a work-related musculoskeletal disorder of the shoulder (OR 3.2, 95\% Cl 1.1 to 8.9 ), hand or wrist (OR 3.1,95\% Cl 1.1 to 8.4 ) and knee (OR $3.5,95 \% \mathrm{Cl} 1.3$ to 9.2). However, there is limited data on the effects of the duration of exposure to factors of physical loads. Long exposure seems to increase the risk of some disorders of the neck and upper limbs and musculoskeletal disorders in general (27).

The association between psycho-social factors and musculoskeletal disorders are reported by many authors (28-31). Many researchers have suggested that the etiology of WMSD is complex, poorly understood and involves not only the physical work environment, but also psychosocial job factors (1). Several epidemiological studies have considered the relation between exposure to physical loads at work and musculoskeletal disorders (32). Identifying and acting on modifiable or preventable risk factors for such common painful conditions would significantly improve the health of adult populations. Musculoskeletal disorders are one of the most frequent reasons for long-term sickness absence, and those of the neck and upper limb account for approximately three-quarters of work-related musculoskeletal disorders seen by UK rheumatologists (33).

There is international agreement that WMSDs are a serious problem and that many can be prevented by improved work designs. Prevention strategies include both workplace-based and healthcare-based interventions. There is increasing recognition 
that an integrated approach including both types of intervention is needed to tackle the problem effectively. In the workplace, there is growing support for the effectiveness of ergonomic interventions based on a "holistic" or systems approach that considers the effect of the equipment, the work environment and the work organization as well as the worker. The full participation of workers in the ergonomics approach is important to its effectiveness. A summary of the main prevention strategies for both primary prevention (eliminating the causes) and secondary prevention (treatment and rehabilitation) follows.

The most cost-effective way to prevent these disorders is to integrate prevention into industrial practices. Today, industry is in constant evolution. New technology and rapidly changing marketing and production strategies influence job content and the need for flexible work schemes. Also, WMSD prevention takes place in this changing context and challenges the classical prevention strategies created under more static conditions. For example, worker selection and traditional medical check-ups are inefficient and regular plant walk-throughs are expensive and the results are meager (34).

Musculoskeletal disorders are a common problem among textile workers. The RULA scores of textile workers have been found to be higher according to RULA scale (1-7). More detailed studies of the frequency of postural changes, as well as an observation of individually adopted postures and working conditions are necessary.

Work-related and personal factors were associated with the increased prevalence of moderate or severe upper-body musculoskeletal pain among garment workers. Owners of sewing companies may be able to reduce or prevent WMSDs among employees by adopting rotations between different types of workstations thus increasing task variety; by either shortening work periods or increasing rest periods to reduce the work-rest ratio and by improving the organization to control psychosocial stressors.

Employers can prevent WMSD hazards by properly designing the jobs or workstations and selecting the appropriate tools or equipment. Based on information from the job analysis, an employer can establish procedures to correct or control risk factors by using:

- Appropriate engineering controls such as workstation, tool and equipment designs or redesigns.

- Work practices such as proper lifting techniques and keeping work areas clean.

- Administrative controls such as worker rotation, more task variety and increased rest breaks.

- Personal protective equipment such as knee pads, vibration gloves and similar devices.

Ethics Committee Approval: Ethics committee approval was received for this study.

Informed Consent: Written informed consent was obtained from patients who participated in this study.

Peer-review: Externally peer-reviewed.

Author contributions: Concept - U.B., B.T.; Design - U.B., B.T.; Supervision - U.B., B.T.; Resource - U.B., B.T.; Materials - U.B., B.T.; Data Collection\&/ or Processing - U.B., B.T.; Analysis\&/or Interpretation - U.B., B.T.; Literature
Search - U.B., B.T.; Writing - U.B., B.T.; Critical Reviews - U.B., B.T.

Conflict of Interest: No conflict of interest was declared by the authors.

Financial Disclosure: No financial disclosure was declared by the authors.

\section{References}

1. Bernard B (ed.), Musculoskeletal Disorders and Workplace Factors;A Critical Review of Epidemiologic Evidence for WorkRelated Musculoskeletal Disorders of the Neck, Upper Extremity, and Low Back (NiOSH, 1997), Available from:www.cdc.gov/ niosh/ergosci1.html

2. Detels R, McEwen J, Beaglehole R, Tanaka H (editors), Oxford Textbook of Public Health. Kelsey JL, Sowers M, Musculoskeletal Diseases, 4 th Edition, New York :Oxford University Press, 2002;349-68.

3. Wallace RB (editor), Maxcy-Rosenau-Last, Public Health \& Preventive Medicine. Keyserling WM, Armstrong TJ, Ergonomics and Work-Related Musculoskeletal Disorders, 14 th Edition, Appleton \&Lange;Stamford, USA, 1998:645-59.

4. Hagberg $M$, Silverstein $B$, Wells R, Smith MJ, Hendrick HW, Carayon P, Perusse M, 1995. Work-related Musculoskeletal Disorders (WMSDS):a Reference Book for Prevention, in:Detels $R$, McEwen J, Beaglehole R, Tanaka H (Eds.), Oxford Textbook of Public Health, 4 th Edition, Oxford University Press, New York.

5. Punnett L, Ergonomics and Public Healh, 4 th Edition, New York:Oxford University Press, 2002. p.1067-82.

6. Cakmak ZA, Tekbas FO, Guler C. Work-related Musculoskeletal Disorders and Preventation of Additional İnjuries, Guler C (ed.), Sağlık Boyutuyla Ergonomi, Ankara :Palme Press, 2004;227-54.

7. United States Department of Labor. Workplace injuries and illnesses in 1999. Bureau of Labor Statistics, USDL 00-357, 2000.

8. Palmer K, Cooper C. Repeated movements and repeated trauma affecting the musculoskeletal system. In:Adams PH, Aw T-C, Cockcroft $A$, et al, eds. Hunter's diseases of occupations, 9th edn. London, 2000.

9. http://osha.europa.eu/en/topics/msds/index_html/facts_html (Available from, 2009 March 25).

10. http://osha.europa.eu/en/publications/annual_report/issue_annual_report_2007/view, (Available from, 2008 October 21).

11. Jansen JP, Burdorf A. Effects of measurement strategy and statistical analysis on dose-response relations between physical workload and low back pain. Occup Environ Med 2003;60:942-7. [CrossRef]

12. http://osha.europa.eu/legislation (Avaliable from, 2009 May 15).

13. International Labour Office Geneva. Labour practices in the footwear, leather, textiles, and clothing industries, 10-162000. Geneva:International Labour Organization (ILO), TML$\mathrm{Fl} / 2000.8-1,2004$.

14. Wang PC, Rempel DM, Harrison RJ, Chan J, Ritz BR. Work-organisational and personal factors associated with upper body musculoskeletal disorders among sewing machine Operators. Occup Environ Med 2007;64:806-13. [CrossRef]

15. World Trade Organization;"International Trade Statistics 2010, Avaliable from URL:www.wto.org

16. Turkey Statistical Institute Records, 2009 May 15, Available from URL:http://www.tuik.gov.tr/VeriBilgi.do

17. McAtamney L, Corlett EN., Reducing The Risks of Work-Related Upper Limb Disorders A Guide and Methods, Institue for Occupational Ergonomics, University of Nottingham, 2nd Reprinted, United Kingdom, 1996.

18. McAtamney L, Corlett EN. RULA:A survey Method for Investigation of Work-Related Upper Limb Disorders. Appl Ergon 1993;24:91-9. [CrossRef]

19. Punnett $L$. Adjusting for the healthy worker selection effect in crosssectional studies. Int J Epidemiol 1996;25:1076-86. [CrossRef]

20. Sokas RK, Spiegelman D, Wegman DH. Self-reported musculoskeletal complaints among garment workers. Am J Ind Med 1989;15:197-206. [CrossRef] 
21. Ulu N, Cakmak ZA. The relation of lumbago and working posture aspect of ergonomic in working life. Turkiye Klinikleri J Neur 2009;4:7-18.

22. Hagberg $M$, Wegman $D$. Prevalence rates and odds ratios of shoulder-neck diseases in different occupational groups. Br J Ind Med, 1987;44:602-10.

23. Picavet HSJ, van Gils HWV, Schouten JSGA., Klachten van het bewegingsapparaat in de Nederlandse bevolking:prevalenties, consequenties en risicogroepen [Musculoskeletal complaintsin the Dutch population:prevalences, consequences and risk groups]. Bilthoven (The Netherlands):Rijksinstituut voor volksgezondheid en milieu (RIVM), 2000.

24. Linton SJ, Hellsing AL, Halldén K. A population-based study of spinal pain among 35-45-year-old individuals:prevalence, sick leave, and health care use. Spine 1998;23:1457-63. [CrossRef]

25. Jansen JP, Morgenstern $H$, Burdorf A. Dose-response relations between occupational exposures to physical and psychosocial factors and the risk of low back pain. Occup Environ Med 2004;61:972-9. [CrossRef]

26. Lemasters GK, Atterbury MR, Booth-Jones AD, Bhattacharya A, Ollila-Glenn N, Forrester C, et al. Prevalence of work related musculoskeletal disorders in active union carpenters. Occup Environ Med 1998;55:421-7. [CrossRef]
27. Punnett L. Ergonomic stressors and upper extremity disorders in vehicle manufacturing:cross sectional exposure response trends. Occup Environ Med 1998;55:414-20. [CrossRef]

28. Buckle P. Upper limb disorders and work:the importance of physical and psychosocial factors. J Psychosom Res 1997;43:17-25. [CrossRef]

29. Toomingras A, Theorell T, Michelsen H, Nordemar R. Associations between self-rated psychosocial work conditions and musculoskeletal symptoms and signs. Stockholm MUSIC I Study Group. Scand J Work Environ Health 1997;23:130-9. [CrossRef]

30. Theorell T, Harms-Ringdahl K, Ahlberg-Hultén G, Westin B. Psychosocial job factors and symptoms from the locomotor system--a multicausal analysis. Scand J Rehabil Med 1991;23:165-73.

31. Bongers PM, de Winter CR, Kompier MA, Hildebrandt VH. Psychosocial factors at work and musculoskeletal disease. Scand J Work Environ Health 1993;19:297-312. [CrossRef]

32. Cherry NM, Meyer JD, Chen Y, Holt DL, McDonald JC. The reported incidence of work-related musculoskeletal disease in the UK:MOSS 1997-2000. Occup Med 2001;51:450-5. [CrossRef]

33. Gamperiene $M$, Stigum $\mathrm{H}$. Work related risk factors for musculoskeletal complaints in the spinning industry in Lithuania. Occup Environ Med 1999;56:411-6. [CrossRef]

34. Kort WL, Fransman LG, Dijk FJ. Preemployment medical examinations in a large occupational health service. Scand J Work Environ Health 1991;17:392-7. [CrossRef] 